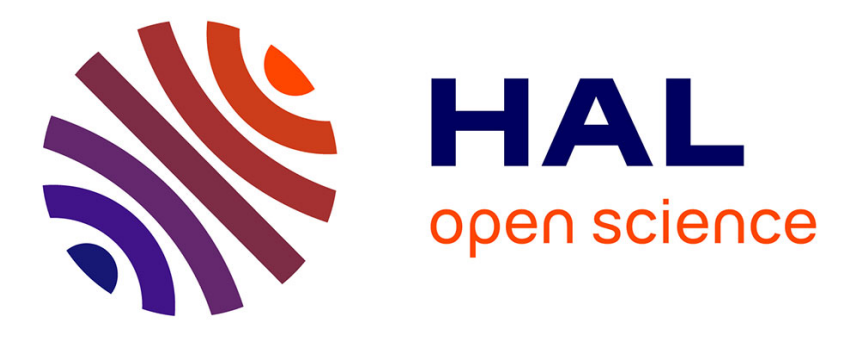

\title{
Improved growth and nutrient status of an oat cover crop in sod-based versus conventional peanut-cotton rotations
}

Duli Zhao, David L. Wright, James J. Marois, Cheryl L. Mackowiak, Meghan Brennan

\section{To cite this version:}

Duli Zhao, David L. Wright, James J. Marois, Cheryl L. Mackowiak, Meghan Brennan. Improved growth and nutrient status of an oat cover crop in sod-based versus conventional peanut-cotton rotations. Agronomy for Sustainable Development, 2010, 30 (2), 10.1051/agro/2009045 . hal-00886550

\section{HAL Id: hal-00886550 https://hal.science/hal-00886550}

Submitted on 1 Jan 2010

HAL is a multi-disciplinary open access archive for the deposit and dissemination of scientific research documents, whether they are published or not. The documents may come from teaching and research institutions in France or abroad, or from public or private research centers.
L'archive ouverte pluridisciplinaire HAL, est destinée au dépôt et à la diffusion de documents scientifiques de niveau recherche, publiés ou non, émanant des établissements d'enseignement et de recherche français ou étrangers, des laboratoires publics ou privés. 


\title{
Improved growth and nutrient status of an oat cover crop in sod-based versus conventional peanut-cotton rotations
}

\author{
Duli ZHAO $^{1 *}$, David L. Wright ${ }^{2}$, James J. MARoIs ${ }^{2}$, Cheryl L. MackowiaK ${ }^{2}$, Meghan BrennaN $^{3}$ \\ ${ }^{1}$ USDA-Agricultural Research Service, Sugarcane Field Station, 12990 US Hwy 441 N., Canal Point, FL 33438, USA \\ ${ }^{2}$ University of Florida, IFAS-North Florida Research and Education Center, 155 Research Rd., Quincy, FL 32351, USA \\ ${ }^{3}$ IFAS Statistics Department, University of Florida, Gainesville, FL 32611, USA
}

(Accepted 9 October 2009)

\begin{abstract}
Nitrogen (N) leaching from agricultural soils is a major concern in the southeastern USA. A winter cover crop following the summer crop rotation is essential for controlling $\mathrm{N}$ leaching and soil run-off, thereby improving sustainable development. Rotation of peanut (Arachis hypogea L.) and cotton (Gossypium hirsutum L.) with bahiagrass (Paspalum notatum) (i.e. sod-based rotation) can greatly improve soil health and increase crop yields and profitability. In the sod-based rotation, the winter cover crop is an important component. The objective of this study was to determine effects of summer crops, cotton and peanut, on growth and physiology of a subsequent oat (Avena sativa L.) cover crop in both a conventional (Peanut-Cotton-Cotton) and sod-based (Bahiagrass-Bahiagrass-Peanut-Cotton) rotations. Two rotations with an oat cover

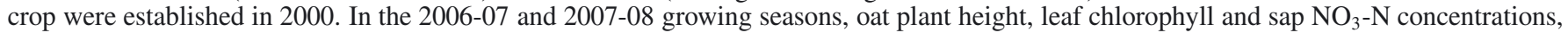
shoot biomass, and $\mathrm{N}$ uptake were determined. Our results showed that the previous summer crop in the two rotations significantly influenced oat growth and physiology. Oat grown in the sod-based rotation had greater biomass, leaf chlorophyll and $\mathrm{NO}_{3}-\mathrm{N}_{\text {concentrations as compared }}$ with oat grown in the conventional rotation. At pre-heading stage, oat in the sod-based rotation had $44 \%$ greater biomass and $32 \%$ higher $\mathrm{N}$ uptake than oat in the conventional rotation; oat following peanut produced 40 to $49 \%$ more biomass and accumulated 27 to $66 \%$ more $\mathrm{N}$ than oat following cotton. Therefore, the sod-based rotation improved not only summer crops, but also the winter cover crop. Increased oat growth and $\mathrm{N}$ status from the sod-based rotation indicated greater soil quality and sustainability.
\end{abstract}

bahiagrass / crop rotation/ oat biomass / nitrogen uptake / soil quality / sustainability

\section{INTRODUCTION}

Conserving soil is a principal goal of sustainable agriculture, as is the preservation of surface water and groundwater quality. Numerous studies have confirmed that a winter cover crop helps to conserve both soil and water quality while allowing succeeding row crops to be grown profitably (Patrick et al., 1957; Kuo et al., 1997; Joyce et al., 2002; Zotarelli et al., 2009). Adding a cover crop to cropping systems can improve productivity and reduce environmental threats from erosion (Langdale et al., 1991; Zuazo and Pleguezuelo, 2008; Spiertz, 2009), nutrient runoff and leaching losses (Meisinger et al., 1991; Sharpley and Smith, 1991; Vidal and López, 2005; Spiertz, 2009), as well as reduce weed pressures (Zotarelli et al., 2009). The additional biomass from a cover crop enhances soil organic matter, improves soil-water dynamics and soil quality (Horton et al., 1994). Unused soil nitrates at the end of summer crop growing season tend to leach from sandy

* Corresponding author: duli.zhao@ars.usda.gov
Coastal Plain soils in the southeast USA and that may result in groundwater contamination. Certain cover crops used in conservation tillage tend to be efficient at recycling or scavenging excess nutrients, especially soil nitrate nitrogen $\left(\mathrm{NO}_{3}-\mathrm{N}\right)$. Additionally, when the cover crop dies or is removed as forage, some of the $\mathrm{N}$ will be released and reused by the subsequent summer crop or utilized as crude protein in the animal feed (Horton et al., 1994).

Cover crops may increase yield potential and/or reduce the amount of additional $\mathrm{N}$ fertilizer required by a succeeding crop, depending on the type of cover crop, rotation system (Reeves et al., 1995; Newman et al., 2007a), and production management (Zotarelli et al., 2009). Most recently, Zotarelli et al. (2009) reported that at lowest supplemental $\mathrm{N}$ rates, the potential cover crops yield benefits to sweet corn (Zea mays L.) were greatest in Florida, USA. Developing more environmental friendly and diverse cropping or farming systems can improve resource, especially $\mathrm{N}$, use efficiency and sustainability (Katsvairo et al., 2006; Spiertz, 2009). 
Studies have shown that rotating peanut and cotton with perennial grasses such as bahiagrass in a sod-based crop rotation system, improves soil health, reduces pest risks, and increases crop yields, quality and profits (Marois et al., 2002; Wright et al., 2004; Katsvairo et al., 2006, 2007). Including a winter cover crop in a sod-based peanut-cotton rotation also enhances the benefits gained by using conservation tillage. To protect highly erodible soils, like those in the southeastern USA, emphasis has been placed on leaving as much residue as possible on fields during the winter. Reduced tillage and conservation cropping systems have increased markedly in the region. As a result, most of north Florida croplands (primarily peanuts, cotton, corn, and soybeans), have roughly $60 \%$ covered with crop residue after harvest. However, peanuts and soybeans produce relatively little residue and the residue decomposes rapidly. Also, soil aggregates are less stable under these crops than with perennial grass rotations (Katsvairo et al., 2006). Therefore, farmers in the region still face a high risk of soil erosion and soil nutrient leaching losses (Newman et al., 2007a).

Mild climatic conditions in the southeastern USA are favorable for winter cover crops. Horton et al. (1994) reported that an oat cover crop had a dramatic effect on soil erosion and runoff. Their simulated rainfall tests resulted in an $84 \%$ reduction in sediment loss from their oat cover crop plots. Cover crops are also an attractive means for scavenging the soil profile for inorganic $\mathrm{N}$, thus lessening the potential for winter and spring nitrate leaching, while improving the soil $\mathrm{N}$ and organic matter status (Horton et al., 1994; Franzluebbers, 2007), and therefore, increasing agricultural profitability and sustainability (Dabney et al., 2001; Sainju et al., 2002).

Over the past several years, sod-based crop rotations with oat as a winter cover crop have been used in north Florida to investigate long-term soil and summer crop responses to cropping systems and the resulting economic return. Although summer crops, peanut and cotton growth and yield performances in sod-based rotations (Katsvairo et al., 2006, 2007) and the sod peanut with difference tillage methods (Zhao et al., 2009) have been reported, cover crop performance in the cropping system has not been investigated. Winter cover crop is an important component for winter grazing in the sod-based rotation and other cropping systems in the southeast USA; yet little is known about the previous summer crop influence on the winter cover crops. The objectives of this study were to: (1) determine plant growth and shoot biomass production of an oat cover crop and (2) quantify oat shoot N, P and K concentrations and total uptake as affected by the summer crop in the sod-based and conventional rotations.

\section{MATERIALS AND METHODS}

\subsection{Experimental location and treatments}

The experiment was conducted at the University of Florida's North Florida Research and Education Center, Quincy, FL ( $\left.84^{\circ} 33^{\prime} \mathrm{W}, 30^{\circ} 36^{\prime} \mathrm{N}\right)$. The soil used in this study was a Dothan sandy loam (fine-loamy, kaolinitic,

\begin{tabular}{|c|c|c|c|}
\hline & Block 1 & Block 2 & Block 3 \\
\hline \multirow{7}{*}{2006} & Sod peanut & Conv. peanut & $2^{\text {nd }}$-yr bahiagrass \\
\hline & Conv. $1^{\text {st }}-y r$ cotton & $2^{\text {nd }}-y r$ bahiagrass & Sod cotton \\
\hline & $1^{\text {st }}-y r$ bahiagrass & Sod cotton & Conv. peanut \\
\hline & Conv. peanut & Conv. $2^{\text {nd }}$-yr cotton & Conv. $1^{\text {st }}$-yr cotton \\
\hline & Sod cotton & Sod peanut & $1^{\text {st }}-y r$ bahiagrass \\
\hline & $2^{\text {nd }}-y r$ bahiagrass & Conv. $1^{\text {st }}-y r$ cotton & Sod peanut \\
\hline & Conv. $2^{\text {nd }}$-yr cotton & $1^{\text {st }}$-yr bahiagrass & Conv. $2^{\text {nd }}$-yr cotton \\
\hline \multirow{7}{*}{2007} & Sod cotton & Conv. $1^{\text {st }}$-yr cotton & Sod peanut \\
\hline & Conv. $2^{\text {nd }}$-yr cotton & Sod peanut & $1^{\text {st }}$-yr bahiagrass \\
\hline & $2^{\text {nd }}$-yr bahiagrass & $1^{\text {st }}$-yr bahiagrass & Conv. $1^{\text {st }}$-yr cotton \\
\hline & Conv. $1^{\text {st }}$-yr cotton & Conv. peanut & Conv. $2^{\text {nd }}$-yr cotton \\
\hline & $1^{\text {st }}$-bahiagrass & Sod cotton & $2^{\text {nd }}$-yr bahiagrass \\
\hline & Sod peanut & Conv. $2^{\text {nd }}$-yr cotton & Sod cotton \\
\hline & Conv. peanut & $2^{\text {nd }}$-yr bahiagrass & Conv peanut \\
\hline
\end{tabular}

Figure 1. Treatment layout and field plot arrangement for the 2006 and 2007 crop rotation studies. Oat cover crop was seeded into the cotton and peanut plots after the summer crop harvest. Note: plots are not to scale and bahiagrass plots (shaded) received no oat.

thermic Plinthic Kandiudult). Two rotations, (i) PeanutCotton-Cotton (Conventional rotation) and (ii) BahiagrassBahiagrass-Peanut-Cotton (Sod-based rotation) were compared. Oat (cv. 'Fla 501') was the winter cover crop for both rotations. The two rotation replicate plots were established in 2000. All crop rotation phases were considered as potential treatments. However, oat winter cover crop was seeded in only the previous summer's peanut and cotton plots. Thus, there were five treatments for the cover crop study (Fig. 1).

As background, bahiagrass established in the spring of the sod-based rotation required a spring application of a combination fertilizer of $560 \mathrm{~kg} \mathrm{ha}^{-1}$, containing 5.0-4.4-12.5\% of N-P-K, that was broadcast immediately before seeding bahiagrass. First-yr bahiagrass was mowed twice to reduce weed competition, while second-yr bahiagrass was cut three times for hay in early July, late August, and mid October. The preceding cotton crop received $\mathrm{N}, \mathrm{P}$, and $\mathrm{K}$ at 28,56 , and $84 \mathrm{~kg}$ $\mathrm{ha}^{-1}$, respectively, at seeding and an additional $67 \mathrm{~kg} \mathrm{~N} \mathrm{ha}^{-1}$ was sidedressed at first square stage in each year. There was no fertilizer requirement, based on soil analysis and the Florida peanut production recommendations, for the preceding peanut crop.

The oat seeding in both crop rotations and different preceding summer crops (peanut and cotton), received comparable soil fertility management, in order to determine effects of rotation and the preceding crop culture on oat. Based on the regional cover crop production management recommendations (Newman et al., 2007b), a rate of $45 \mathrm{~kg} \mathrm{~N}^{-1}$ as ammonium nitrate was broadcasted on 6 February 2007 [60 days after seeding (DAS)] or 4 February 2008 (79 DAS) for all plots except the sod-based cotton plots (bahiagrass seed would be sown after terminating oat in spring). Omitting $\mathrm{N}$ fertilizer to plots planned for bahiagrass spring seeding is a common practice in sod-based rotation management. 


\subsection{Measurements}

Oat was seeded at a rate of $72 \mathrm{~kg} \mathrm{ha}^{-1}$ in $17.8 \mathrm{~cm}$ row spacings in all plots on 8 December 2006 and 17 November 2007, using a Great Plains no-till drill (Great Plains Mfg., Assaria, KS), after harvesting cotton and peanut and mowing down the cotton stalks. Oat plant height, shoot biomass, leaf chlorophyll (i.e. leaf greenness), and leaf sap $\mathrm{NO}_{3}-\mathrm{N}$ concentration were determined biweekly starting from 41 DAS until pre-heading (102 DAS) in 2007 or 112 DAS in 2008. Plant height was measured from soil surface to the last collared extended leaf held upright. Leaf chlorophyll was estimated on 10 upper mostfully expanded leaves randomly collected from 10 plants in each plot, using a SPAD-502 chlorophyll meter (Minolta Co., LTD., Japan). At the same time, 20 leaves at the same position in each plot were removed in order to collect leaf sap for measuring $\mathrm{NO}_{3}-\mathrm{N}$ concentration using a C-141 CARDY meter (Horiba, LTD., Kyoto, Japan). Oat shoot biomass was estimated by cutting a 1-meter row of plants to a $1 \mathrm{~cm}$ stubble height from each plot at all sampling dates. A new section was sampled in the plots at each date (no repeated cuttings). Plant shoot samples were dried in a forced air oven at $65^{\circ} \mathrm{C}$ for $72 \mathrm{~h}$ and weighed.

For the last sampling date (102 DAS at pre-heading) in 2007 and at all sampling dates in 2008, oven-dried tissues were ground in a Wiley mill (Arthur H. Thomas Co., Philadelphia, PA) to pass a 1-mm screen. The ground tissue was sent to a commercial analytic laboratory (Waters Agricultural Laboratories, Inc., Camilla, GA) for mineral nutrient analyses using standard methods. Tecator Kjeltec Model 1030 Auto Analyzer (Tecator, Eden Prairie,MN) was used to determine total N concentration in the tissues after ground samples were digested with sulfuric acid (Baker and Thompson, 1992). After the samples were digested in nitric acid/ peroxide, ICP spectrometry was used to determine mineral element contents (Donohue and Aho, 1992). Oat total N, P, and K uptake was estimated by multiplying the shoot biomass at the end of the season by tissue $\mathrm{N}, \mathrm{P}$, and $\mathrm{K}$ concentrations, respectively. Glyphosate [N(phosphonomethyl) glycine] herbicide was applied to terminate oat following the final sampling, in preparation for the succeeding summer crops.

Soil samples were collected from 0 to $18 \mathrm{~cm}$ depth on 29 January 2008 in all plots. Air-dry soil samples were sent to the Waters Agricultural Laboratories, Inc. (Camilla, GA) for analyses of soil $\mathrm{NO}_{3}-\mathrm{N}, \mathrm{NH}_{4}-\mathrm{N}, \mathrm{P}$ and $\mathrm{K}$ concentrations. Soil penetration resistance was measured once in all plots for each growing season (16 Feb. 2007 and 18 Apr. 2008). The soil resistance was determined from 0 to $50 \mathrm{~cm}$ soil depths at $2-\mathrm{cm}$ increments, using a CP-20 cone penetrometer (Rimik Agricultural Electronics, Brisbane, Australia) in 2007 or by a tractor mounted soil penetrometer with five probes (USDA-NSDL, Auburn, AL) in 2008. Twelve (in 2007) or eight (in 2008) measurements were taken between the two middle rows in each plot.

Weather data, including daily mean air temperature and precipitation, were collected from a weather station located at Quincy, FL (Florida Automated Weather Network: http:// fawn.ifas.ufl.edu/). The monthly mean air temperature and cumulative precipitation during oat cover crop growth (from October to May) were compared with 20-yr (1985-2005) averages.

\subsection{Experimental design and data analysis}

The crop rotation phases were different for the two rotations. There were three phases (peanut-cotton-cotton) in the conventional rotation and four phases (bahiagrass-bahiagrasspeanut-cotton) in the sod-based rotation. Only plots harvested as cotton or peanut were followed by oat (Fig. 1). Therefore, the five treatments seeded in oat were: (1) sod peanut, (2) sod cotton, (3) conventional peanut, (4) conventional 1st-yr cotton, and (5) conventional $2 \mathrm{nd}-\mathrm{yr}$ cotton. The experiment was a randomized complete block design with three replications and five or six repeated measurements for most growth and tissue samplings. Plot size was $24.6 \mathrm{~m}$ long and $18.4 \mathrm{~m}$ wide. To determine main and interactive effects of summer crop and rotation on oat cover crop, oat data from the first- and second-year conventional cotton plots were averaged before doing analysis of variance (ANOVA). The repeated-measures ANOVA was selected using the PROC MIXED model (SAS Institute, 2004) to test the subsequent effects of summer crops in the two rotations on oat performance within a year. Treatment was a fixed factor with block being random, and sampling times were repeated to test for treatment and time effects on oat shoot biomass, plant height, leaf chlorophyll content, leaf sap $\mathrm{NO}_{3}-\mathrm{N}$ concentration, shoot $\mathrm{N}, \mathrm{P}$, and $\mathrm{K}$ concentrations and uptake. Shoot biomass and leaf $\mathrm{NO}_{3}-\mathrm{N}$ data were $\log$ transformed prior to statistical analysis to consider normality of residuals and homogeneity of variance. Trait means that were significantly different at $\alpha=0.05$ were compared using Fisher Least Significant Difference (LSD).

\section{RESULTS AND DISCUSSION}

\subsection{Temperature and precipitation}

Although monthly mean air temperatures were slightly above or below (depending on month and year) the 20-yr longterm averages (data not shown), overall mean air temperatures in $2006-2007\left(14.5^{\circ} \mathrm{C}\right)$ and in $2007-2008\left(15.0^{\circ} \mathrm{C}\right)$ during oat growth from October through April were similar to the longterm average $\left(14.9^{\circ} \mathrm{C}\right)$. Cumulative monthly precipitation during oat growth from October through April was $461 \mathrm{~mm}$ in year 1 and $721 \mathrm{~mm}$ in year 2, which are $45 \%$ and $14 \%$ less, respectively, than the long-term average of $834 \mathrm{~mm}$. Therefore, year 1 was dry and year 2 was equivalent to normal. Differences in precipitation between the two test years may explain, in part, the somewhat less early oat growth in year 1.

\subsection{Plant height and shoot biomass}

Dynamics of seasonal oat plant height and shoot biomass accumulation were similar for both rotations and followed a 


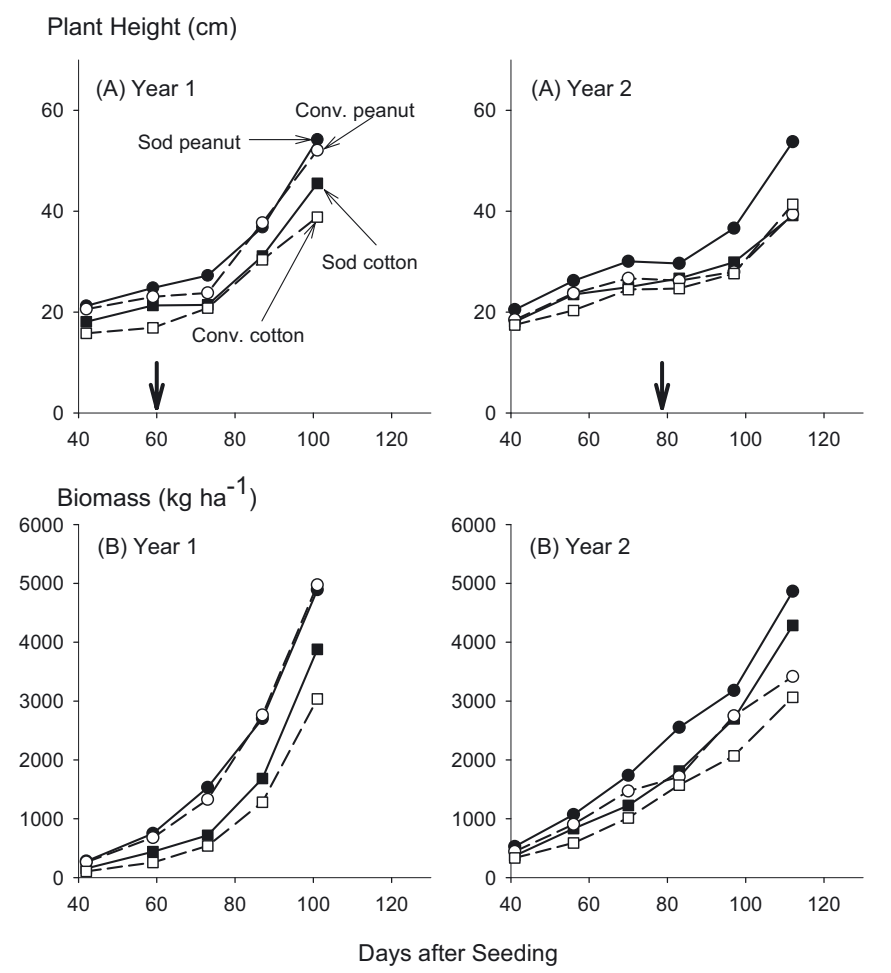

Figure 2. Plant height (A) and shoot biomass (B) of oat as affected by crop rotations (sod vs. sonvention) and previous crops (peanut vs. cotton). Closed circles $=$ sod-based peanut, open circles = conventional peanut, closed squares $=$ sod-based cotton, open squares $=$ conventional cotton. Oat in the sod-based rotation grew better with greater shoot biomass compared to oat in the conventional rotation. Vertical arrows indicate $\mathrm{N}$ application dates.

growth pattern typical of winter cover crops. In the first $70 \mathrm{~d}$ (i.e. tillering phase), plant height and shoot biomass increased slowly, and then increased more rapidly, with head formation (Fig. 2). Both sampling date and previous summer crop significantly influenced oat plant height and shoot biomass $(P<0.001)$ and the crop $\times$ sampling date interactions were also significant $(P<0.01)$ during the first growing season.

During the first season of oat growth, oat plant height and biomass in peanut plots were significantly greater than oat in cotton plots at all measurement dates (Fig. 2). At pre-heading (102 DAS), oat in peanut plots $\left(4852 \mathrm{~kg} \mathrm{ha}^{-1}\right)$ had $49 \%$ greater biomass than oat in the cotton plots $\left(3317 \mathrm{~kg} \mathrm{ha}^{-1}\right)$, averaged across rotations. There were no differences in either plant height or shoot biomass of oat grown in peanut plots of either of the two rotations. However, oat grew better (i.e. taller with more shoot biomass) in the sod-based cotton plots than in the conventional cotton plots (Fig. 2). At 102 DAS in year 1, oat in cotton plots of the sod-based rotation had over $22 \%$ greater shoot biomass $(P<0.05)$ compared to oat in the cotton plots of the conventional rotation.

In year 2, oat grown in the sod peanut plots produced more shoot biomass than others at most sampling dates (Fig. 2). Unlike the 2007 harvest that oat biomass was not different between sod peanut and conventional peanut treatments, oat in peanut plots of the sod-based rotation in 2008 produced $41 \%$ more $(P<0.01)$ shoot biomass at final harvest $(112$ DAS) than oat grown in the conventional peanut plots. Shoot biomass of oat grown in the sod-based cotton plots was also $39 \%$ greater $(P<0.05)$ than that of oat in the conventional cotton plots at final harvest. The difference between the two growing seasons in shoot biomass might be associated with precipitation. The second growing season had $160 \mathrm{~mm}$ more precipitation than the first season. Therefore, water deficit in the first growing season might slow down oat growth and eliminate treatment differences as reported in barley (Jamieson et al., 1995) and wheat (Giunta et al., 1995). In the southeastern USA, a cover crop can be used as pasture or hay for livestock (Franzluebbers, 2007) or the crop can be killed without cutting and returned to the soil to increase soil organic matter and fertility, as was done for this study. Our oat biomass data may provide useful information for regional growers to know how much dry matter can be available for grazing animals in the growing season under low and moderate precipitation.

\subsection{Leaf chlorophyll and $\mathrm{NO}_{3}-\mathrm{N}$ concentrations}

During the first growing season (year 1), oat leaf chlorophyll increased between 42 and 73 DAS and it reached a plateau following flag leaf emergence (Fig. 3A). The previous summer crop and sampling date significantly influenced oat leaf chlorophyll content $(P<0.001)$. Oat grown in peanut plots had greater chlorophyll values (SPAD readings) as compared with oat grown in cotton plots over the first three sampling dates, indicating better plant $\mathrm{N}$ status for oat in summer peanut plots than oat in cotton plots during early growth because SPAD meter is commonly used for predicting crop $\mathrm{N}$ status (Wood et al., 1992). Leaf chlorophyll values were not statistically different among treatments at 87 DAS. In year 2, treatment differences in leaf chlorophyll content were relatively minor. As expected, sampling date affected leaf SPAD readings, but the previous crop did not.

Leaf sap $\mathrm{NO}_{3}-\mathrm{N}$ concentrations changed during oat growth (Fig. 3B), following a pattern similar to that of leaf chlorophyll contents (Fig. 3A) in year 1. About 2 weeks after $\mathrm{N}$ fertilizer application (73 DAS), both leaf chlorophyll and $\mathrm{NO}_{3}-\mathrm{N}$ peaked. Overall, leaf sap $\mathrm{NO}_{3}-\mathrm{N}$ was affected by both sampling date and treatments, but the treatment differences in leaf $\mathrm{NO}_{3}-\mathrm{N}$ content were detected before $\mathrm{N}$ application rather than after $\mathrm{N}$ application (Fig. 3). In year 2, both the previous crop and sampling date significantly $(P<0.05)$ affected sap $\mathrm{NO}_{3}-$ $\mathrm{N}$ content. Leaf $\mathrm{NO}_{3}-\mathrm{N}$ peaked around 83 DAS of the second growing season. Thereafter, leaf $\mathrm{NO}_{3}-\mathrm{N}$ concentration declined sharply as plants aged. When averaged across sampling dates, there were no treatment differences in leaf sap $\mathrm{NO}_{3}-\mathrm{N}$ concentration in year 1 . However, oat grown in peanut plots had higher leaf $\mathrm{NO}_{3}-\mathrm{N}$ content than oat in cotton plots at most sampling times in year 2 . The peak in leaf sap $\mathrm{NO}_{3}-\mathrm{N}$ around 73 or 83 DAS was associated with $\mathrm{N}$ fertilizer application (Fig. 3). The greater leaf $\mathrm{NO}_{3}-\mathrm{N}$ concentration of oat from peanut plots was likely attributed to greater soil $\mathrm{N}$ availability associated with the previous leguminous peanut in year 2 
Table I. Soil nitrate nitrogen $\left(\mathrm{NO}_{3}-\mathrm{N}\right)$, ammonium nitrogen $\left(\mathrm{NH}_{4}-\mathrm{N}\right)$, phosphorus, and potassium concentrations $(0$ to $18 \mathrm{~cm}$ depth increment) during the oat tillering stage (29 January 2008).

\begin{tabular}{|c|c|c|c|c|c|}
\hline Rotation & Previous crop & $\mathrm{NO}_{3}-\mathrm{N}$ & $\mathrm{NH}_{4}-\mathrm{N}$ & Phosphorus & Potassium \\
\hline & & & & $\mathrm{ng} \mathrm{kg}^{-1}$ & \\
\hline \multirow[t]{2}{*}{ Sod-based } & Peanut & 6.7 & 2.2 & 17.2 & 33.7 \\
\hline & Cotton & 7.2 & 1.6 & 26.6 & 89.2 \\
\hline \multirow[t]{2}{*}{ Conventional. } & Peanut & 7.4 & 2.5 & 32.8 & 86.4 \\
\hline & Cotton $^{\dagger}$ & 6.7 & 1.7 & 32.6 & 91.3 \\
\hline $\mathrm{LSD}_{0.05}$ & & NS & 0.6 & 4.3 & 7.3 \\
\hline
\end{tabular}

${ }^{\dagger}$ Means of the conventional first- and second-year cotton plots.
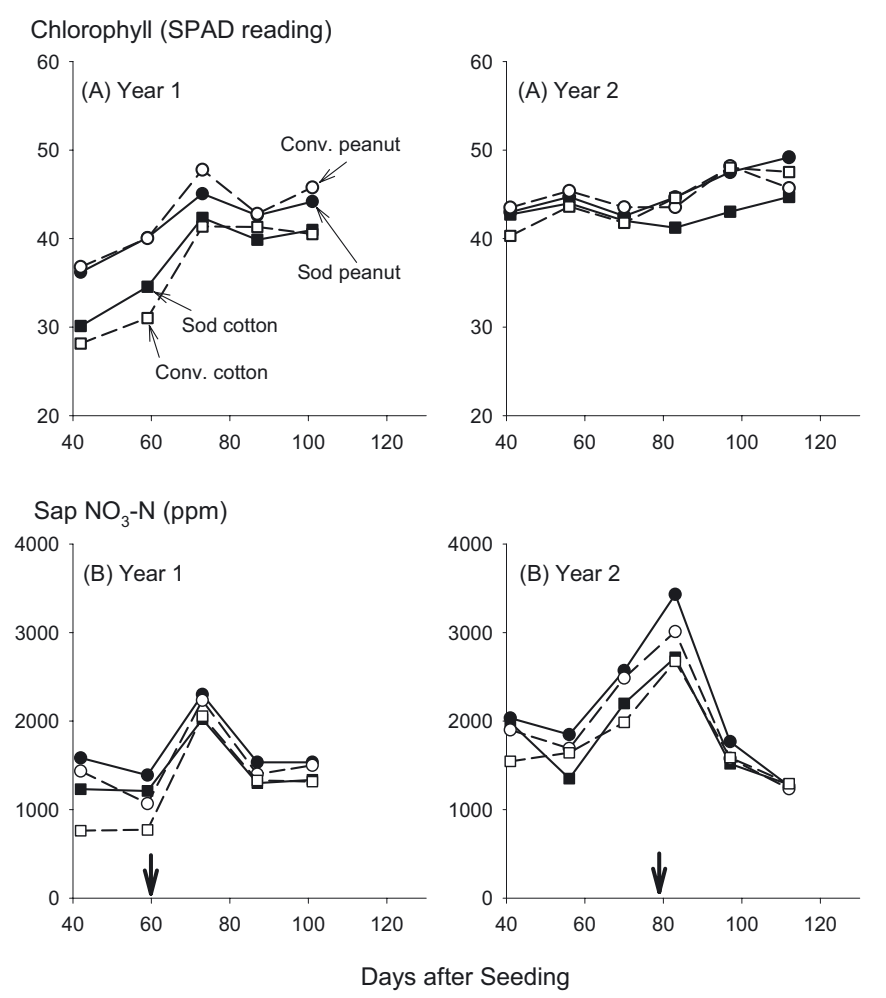

Figure 3. Changes in leaf chlorophyll (A) and leaf sap $\mathrm{NO}_{3}-\mathrm{N}(\mathrm{B})$ of oat during growth as affected by crop rotations ( and previous crops (peanut vs. cotton). Treatment differences in leaf $\mathrm{NO}_{3}-\mathrm{N}$ and chlorophyll were only detected at early stage. Vertical arrows indicate $\mathrm{N}$ application dates.

(Tab. I). Although both leaf SPAD reading (Wood et al., 1992) and $\mathrm{NO}_{3}-\mathrm{N}$ (Hartz et al., 1993) were indicators of plant $\mathrm{N}$ status, the relationship between them was not linear in oat (data not shown) which are consistent with a report by Sunaga et al. (2006) in Italian ryegrass (Lolium multiflorum Lam.).

\subsection{Shoot N, P, and K dynamics}

Only year 2 tissue composition of all sampling dates was determined. From 40 to 80 DAS, oat shoot $\mathrm{N}$ concentrations linearly declined as plants grew and bottomed out by 80 to
112 DAS (Fig. 4). Neither the preceding summer crop nor rotation affected the $\mathrm{N}$ concentration of oat shoots. Decline in oat shoot $\mathrm{N}$ concentration with growth and no differences among treatments in oat shoot $\mathrm{N}$ concentration at most sampling dates were likely due to 'dilution effect' because oat gown in peanut or the sod-based rotation plots generally produced greater shoot biomass compared to the conventional rotation (Fig. 2). These results support an earlier report of Lynch et al. (2004) who did not observe effect of fertility treatments on forage $\mathrm{N}$ concentration. The difference between the two rotations in shoot $\mathrm{N}$ concentration of oat following cotton was associated with differences in $\mathrm{N}$ fertilizer applications as oat in the sod-based cotton plots did not receive any $\mathrm{N}$ fertilizer application. This is a common farming practice when preparing the field for bahiagrass seeding the following spring in the region. Nitrogen uptake increased linearly with plant age for all the treatments. Starting from 70 DAS, oat grown in the sodbased peanut plots accumulated significantly greater amounts of $\mathrm{N}$ than oat in other treatments. This was mainly associated with a greater amount of shoot biomass (Fig. 2) rather than big differences in shoot $\mathrm{N}$ concentration (Fig. 4).

Shoot $\mathrm{P}$ concentration changed little between 40 and 60 DAS, but declined sharply from 60 to 90 DAS, when it leveled off (Fig. 4). Oat in peanut plots (especially in the sod-based rotation) had lower shoot $\mathrm{P}$ concentration at most sampling dates compared to oat in cotton plots. Decreased tissue P concentration for oat grown in sod peanut plots was associated with lower soil P content in those treatments (Tab. I).

Shoot K dynamics during the 2008 growing season was similar to that of shoot P (Fig. 4), but there were no differences among treatments in shoot $\mathrm{K}$ concentration for most sampling dates although the sod peanut plots had much lower soil $\mathrm{K}$ content than other treatments, which corresponded to shoot biomass dilution (Tab. I). As expected, oat N, P and K accumulation increased over time. Oat grown in sod peanut plots accumulated more $\mathrm{P}$ and $\mathrm{K}$ on most sampling dates, due to greater biomass.

\subsection{Soil $\mathbf{N}, \mathbf{P}$ and $K$ contents and penetration resistance}

Soil analyses in the second growing season from 0 to $18 \mathrm{~cm}$ on 29 January 2008 (tillering stage) indicated that soil $\mathrm{NO}_{3}$ $\mathrm{N}$ content did not differ among treatments, but soil $\mathrm{NH}_{4}-\mathrm{N}$ 


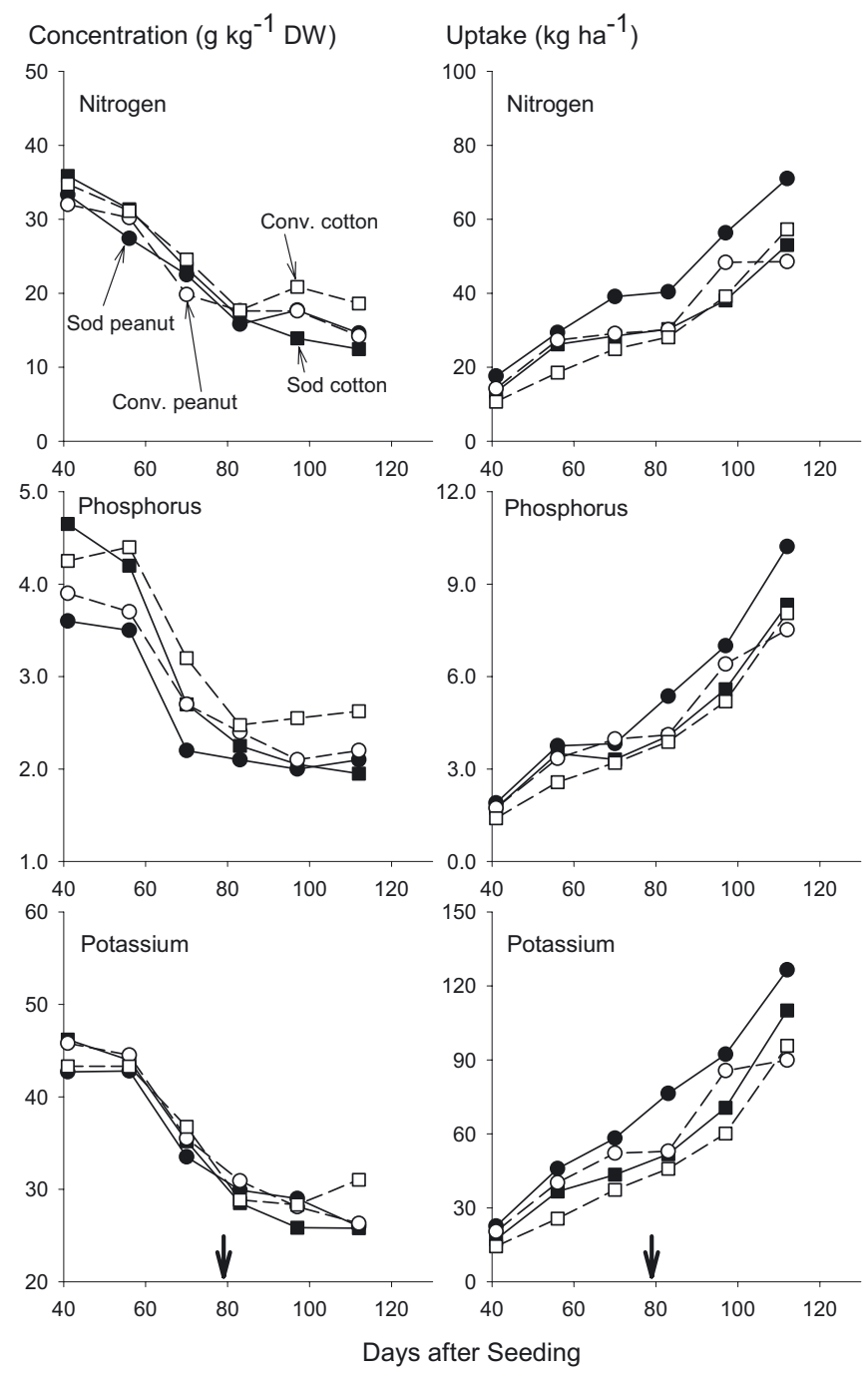

Figure 4. Concentrations of nitrogen, phosphorus, and potassium in oat shoot and uptake during the second growing season, as affected by crop rotations (sod vs. convention) and previous crops (peanut vs. cotton). Treatments had a greater effect on the oat $\mathrm{N}, \mathrm{P}$, and $\mathrm{P}$ uptake than they did on oat shoot concentrations. Vertical arrows indicate $\mathrm{N}$ application date.

content in peanut plots was greater $(P<0.05)$ than that in cotton plots (Tab. I). Averaged across the two rotations, peanut plots $\left(2.4 \mathrm{mg} \mathrm{kg}^{-1}\right)$ had a $41 \%$ higher soil $\mathrm{NH}_{4}-\mathrm{N}$ than the cotton plots $\left(1.7 \mathrm{mg} \mathrm{kg}^{-1}\right)$. These results support previous findings from sod-based rotations improving soil $\mathrm{N}$ status reported by Reeves (1997), Wright et al. (2004), and Katsvairo et al. (2006). Rotation system and preceding summer crop significantly affected available soil $\mathrm{P}$ and $\mathrm{K}$ contents $(P<0.05)$. Some interactions of rotation and summer crop in available soil $\mathrm{P}$ and $\mathrm{K}$ contents were also detected. For instance, soil $\mathrm{P}\left(33 \mathrm{mg} \mathrm{kg}^{-1}\right)$ did not differ among preceding crops in the conventional rotation, while soil $\mathrm{P}$ content in the sod peanut plots $\left(17.2 \mathrm{mg} \mathrm{kg}^{-1}\right)$ was much lower than that in the sod cotton plots $\left(26.6 \mathrm{mg} \mathrm{kg}^{-1}\right)$. The sod-based peanut plots also had

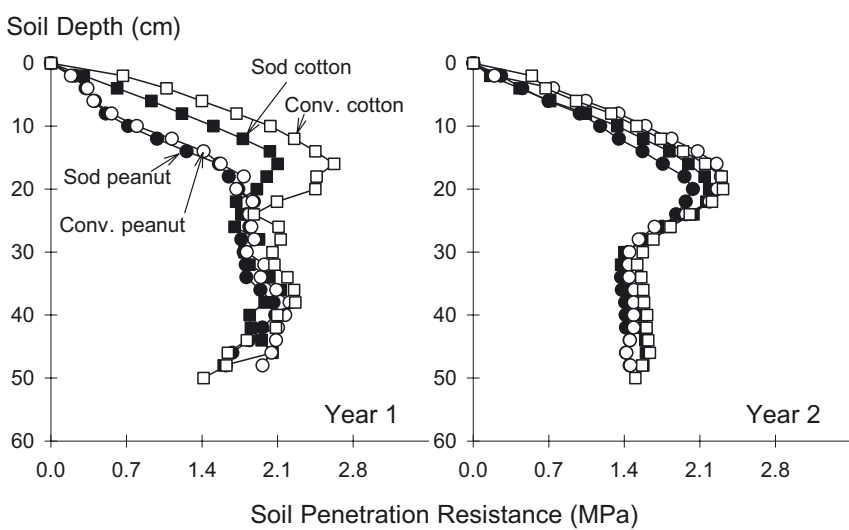

Figure 5. Soil mechanical resistance during oat tillering, as affected by crop rotations (sod vs. convention) and previous crops (peanut vs. cotton). Soil resistance was lower in peanut plots than in cotton plots and the sod-based rotation reduced soil resistance compared to the convention rotation. Data are means of multiple measurements from all replicates ( $\mathrm{n}=36$ in 2007 and $n=120$ in 2008).

lowest soil $\mathrm{K}$ content $(P<0.01)$ among treatments (Tab. I). Results of low soil $\mathrm{P}$ and $\mathrm{K}$ contents in sod-based rotation, especially sod peanut plots, suggested that bahiagrass and peanut might remove more these elements from soils. Therefore, it is important to rely on soil test results when determining fertilizer application for these different systems.

The rotation and previous summer crop considerably affected soil mechanical resistance, especially at the depth of 0 to $25 \mathrm{~cm}$ (Fig. 5). The sod-based rotation had lower soil resistance than the conventional rotation. Soil with previous peanut had lower penetration resistance, compared to soil with previous cotton. Averaged across years and soil depths from 0 to $25 \mathrm{~cm}$, soil resistances of conventional and sod-based rotations were 1.52 and $1.24 \mathrm{MPa}$, respectively. Studies have suggested that soil compaction or high penetration resistance negatively influence crop root growth and deep soil water and nutrient utilizations, resulting in low dry matter accumulation and economic yields (Arvidsson and Håkansson, 1991; Lipiec et al., 2003). In the present study, we found that the sod-based rotation reduced soil resistance (Fig. 5). Therefore, in addition to improvement of summer crops from the sod-based rotation (Marois et al., 2002; Wright et al., 2004; Katsvairo et al., 2007), enhanced oat growth in the sod-based rotation may be the other indicator of improved soil physical, chemical, and biological properties by bahiagrass based on our soil $\mathrm{NH}_{4}-\mathrm{N}$ and soil resistance results as well as previous reports (Reeves, 1997; Wright et al., 2004; Katsvairo et al., 2006, 2007).

\subsection{System management}

Oat cover crops in the southeast USA may be cut as hay and moved out of the field before planting summer crops or it can be terminated using a glyphosate herbicide, or rolled down, in the case of organic systems. Farmers are interested in how much $\mathrm{N}, \mathrm{P}$ and $\mathrm{K}$ are removed from their fields by harvesting hay or how much of the nutrients are returned to the soils for 
Table II. Total oat shoot nitrogen, phosphorus and potassium uptake during the 2007 and 2008 (year 1 and year 2, respectively) oat growing seasons.

\begin{tabular}{|c|c|c|c|c|c|c|c|}
\hline \multirow[t]{2}{*}{ Rotation } & \multirow[t]{2}{*}{ Previous crop } & \multicolumn{2}{|c|}{ Nitrogen } & \multicolumn{2}{|c|}{ Phosphorus } & \multicolumn{2}{|c|}{ Potassium } \\
\hline & & Year 1 & Year 2 & Year 1 & Year 2 & Year 1 & Year 2 \\
\hline & & \multicolumn{6}{|c|}{$\mathrm{kg} \mathrm{ha}^{-1}$} \\
\hline \multirow[t]{2}{*}{ Sod } & Peanut & 93 & 86 & 13 & 12 & 184 & 152 \\
\hline & Cotton & 66 & 53 & 9 & 8 & 134 & 110 \\
\hline \multirow[t]{3}{*}{ Conv. } & Peanut & 88 & 49 & 11 & 8 & 153 & 90 \\
\hline & Cotton $^{\dagger}$ & 48 & 52 & 7 & 7 & 101 & 79 \\
\hline & $\mathrm{LSD}_{0.05}$ & 16 & 23 & 2 & 3 & 27 & 42 \\
\hline
\end{tabular}

${ }^{\dagger}$ Means of the first- and second-year cotton.

the succeeding summer crops, to aid with their fertilizer management plans. To address these questions, we estimated the oat $\mathrm{N}, \mathrm{P}$, and $\mathrm{K}$ uptake, as affected by crop rotation and preceding summer crop, using shoot forage nutrient concentration and biomass at pre-heading stage (i.e. last sampling: 102 DAS in year 1 and 112 DAS in year 2). The summer crop and rotation significantly $(P<0.05)$ affected oat $\mathrm{N}, \mathrm{P}$ and $\mathrm{K}$ uptakes (Tab. II) in the first year.

Overall, oat grown in peanut plots recovered more $\mathrm{N}$ in shoots than oat grown in cotton plots and the sod-based rotation had greater oat shoot $\mathrm{N}$ recovery than the conventional system (Tab. II). But in the second growing season, only oat in the sod-based peanut plot recovered more $\mathrm{N}$ than other treatments. Averaged across the two growing seasons, 89 and $68 \mathrm{~kg} \mathrm{~N} \mathrm{ha}^{-2}$ were recovered in shoot biomass of oat grown in peanut plots of sod-based and conventional rotations, respectively at pre-heading (100 to 110 DAS). Although oat grown in cotton plots of the sod-based rotation did not receive fertilizer $\mathrm{N}$, it accumulated $60 \mathrm{~kg} \mathrm{~N} \mathrm{ha}^{-1}$ in shoot biomass at the preheading. Oat grown in cotton plots of the conventional rotation with $45 \mathrm{~kg} \mathrm{~N}$ application recovered only $50 \mathrm{~kg} \mathrm{~N}^{-1}$ at the same stage (Tab. II). Averaged across summer crops and years, oat in the sod-based rotation recovered $32 \%$ more $\mathrm{N}$ than oat in the conventional rotation at pre-heading. Nitrogen recovered by an oat cover crop effectively prevents soil $\mathrm{N}$ leaching (Muller et al. 1987; Meisinger et al. 1991; Sharpley and Smith, 1991; Vidal and López, 2005; Spiertz, 2009) and can directly benefit the summer crop (Sullivan et al., 1991), as the residues decompose.

Oat $\mathrm{P}$ and $\mathrm{K}$ uptake in response to preceding crops and rotations were similar to the $\mathrm{N}$ recovery response (Tab. II). Averaged across the two growing seasons, oat from the sod peanut plots had a $39 \%$ greater $\mathrm{P}$ and $\mathrm{K}$ recovery than oat from the conventional peanut plots. Phosphorus recovery by oat grown in cotton plots did not differ between the two crop rotations, but $\mathrm{K}$ recovery of oat in the sod-based cotton plots were $29 \%$ higher than that of oat in conventional cotton plots. Therefore, crop fertilizer requirements and nutrient management may need to include additional information beyond soil sampling, such as the rotation system and the previous summer crop.

\section{CONCLUSION}

Results from this study indicated that both crop rotation and the summer crop influenced oat cover crop growth, shoot biomass accumulation, plant $\mathrm{N}, \mathrm{P}$, and $\mathrm{K}$ contents and uptake. Oat grown in plots of the sod-based rotation had greater biomass, leaf chlorophyll and leaf sap $\mathrm{NO}_{3}-\mathrm{N}$ concentrations as compared to oat grown in the conventional rotation. Oat grown in peanut plots had much greater biomass production and greater tissue $\mathrm{N}$ concentrations than oat grown in cotton plots. The increases in cover crop plant growth and $\mathrm{N}$ status found in the sod-based peanut plots were associated with improved soil physical properties, soil fertility, and perhaps other soil quality parameters contributed by the bahiagrass sod. The data gathered from this study can help demonstrate to growers the benefit of growing an oat cover crop and it may help provide $\mathrm{N}, \mathrm{P}$ and $\mathrm{K}$ fertilizer management insight for cotton and peanut nutrient needs in either the sod-based or conventional rotation in the southeastern USA. Our data also may be useful for those producers who manage cover crops for hay or greenchop, by providing them growth response and seasonal nutrient uptake information.

Acknowledgements: This research was supported in part by cooperative research agreements with USDA Special Research Grants and Northwest Florida Water Management District. We thank Brian Kidd, Maynard Douglas, and all other support staff at the North Florida Research and Education Center for their excellent field work and technical assistance.

\section{REFERENCES}

Arvidsson J., Håkansson I. (1991) A model for estimating crop yield losses caused by soil compaction, Soil Till. Res. 20, 319-332.

Baker W.H., Thompson T.L. (1992) Determination of total nitrogen in plant samples by Kjeldahl, in: Plank C.O. (Ed.), Plant Analysis Reference Procedures for the Southern Region of the United States, Southern Cooperative Series Bulletin 368, pp. 13-16.

Dabney S.M., Delgado J.A., Reeves D.W. (2001) Using winter cover crops to improve soil quality and water quality, Commun. Soil Sci. Plan. 32, 1221-1250. 
Donohue S.J., Aho D.W. (1992) Determination of P, K, Ca, Mg, Mn, Fe, $\mathrm{Al}, \mathrm{B}, \mathrm{Cu}$, and $\mathrm{Zn}$ in plant tissue by inductively coupled plasma (ICP) emission spectroscopy, in: Plank C.O. (Ed.), Plant Analysis Reference Procedures for the Southern Region of the United States, Southern Cooperative Series Bulletin 368, pp. 37-40.

Franzluebbers A.J. (2007) Integrated crop-livestock systems in the southeastern USA, Agron. J. 99, 361-372.

Giunta F., Motzo R., Deidda M. (1995) Effects of drought on leaf area development, biomass production and nitrogen uptake of durum wheat grown in a Mediterranean environment, Aust. J. Agr. Res. 46, 99-111.

Hartz T.K., Smith R.F., LeStrange, M., Schulbach K.F. (1993) On-farm monitoring of soil and crop nitrogen status by nitrate-selective electrode, Commun. Soil Sci. Plan. 24, 2607-2615.

Horton R., Kaspar T.C., Kohler K.A. (1994) Fall-planted spring oats: A low-risk cover crop to reduce erosion following soybean, Leopold Center Progress Reports, Vol. 3, pp. 49-52.

Jamieson P.D., Martin R.J., Francis G.S., Wilson D.R. (1995) Drought effects on biomass production and radiation-use efficiency in barley, Field Crop. Res. 43, 77-86.

Joyce B.A., Wallender W.W., Mitchell J.P., Huyck L.M., Temple S.R., Brostrom P.N., Hsiao T.C. (2002) Infiltration and soil water storage under winter cover cropping in California's Sacramento Valley, Trans. ASAE 45, 315-326.

Katsvairo T.W., Wright D.L., Marois J.J., Hartzog D.L., Rich J.R., Wiatrak P.J. (2006) Sod-livestock integration into the peanutcotton rotation: A systems farming approach, Agron. J. 98, 11561171 .

Katsvairo T.W., Wright D.L., Marois J.J., Hartzog D.L., Balkcom K.B., Wiatrak P.P., Rich J.R. (2007) Cotton roots, earthworms, and infiltration characteristics in sod-peanut-cotton cropping systems, Agron. J. 99, 390-398.

Kuo S., Sainju U.M., Jellum E.J. (1997) Winter cover crop effects on soil organic carbon and carbohydrate in soil, Soil Sci. Soc. Am. J. 61, $145-152$.

Langdale G.W., Blevins R.L., Karlen D.L., McCool D.K., Nearing M.A., Skidmore E.L., Thomas A.W., Tyler D.D., Williams J.R. (1991) Cover crop effects on soil erosion by wind and water, in: Hargrove W.L. (Ed.), Cover Crops for Clean Water, Soil Water Conserv. Soc., Ankeny, IA, USA, pp. 15-22.

Lipiec J., Medvedev V.V., Birkas M., Dumitru E., Lyndina T.E., Rousseva S., Fulajtár E. (2003) Effect of soil compaction on root growth and crop yield in Central and Eastern Europe, Int. Agrophys. 17, 61-69.

Lynch D.H., Voroney R.P., Warman P.R. (2004) Nitrogen availability from composts for humid region perennial grass and legume-grass forage production, J. Environ. Qual. 33, 1509-1520.

Marois J.J., Wright D.L., Baldwin J.A., Hartzog D.L. (2002) A multistate project to sustain peanut and cotton yields by incorporating cattle in a sod-based rotation, in: van Santen E. (Ed.), Proc. 25th Ann. South. Conserv. Tillage Conf. Sustain. Agric., Auburn, AL, USA, 24-26 June 2002, Alabama Agric. Exp. Stn., Auburn Univ., USA, pp. 101-107.

Meisinger J.J., Hargrove W.L., Mikkelsen R.L., Williams J.R., Benson V.W. (1991) Effects of cover crops on groundwater quality, in: Hargrove W.L. (Ed.), Cover Crops for Clean Water, Soil Water Conserv. Soc., Ankeny, IA, USA, pp. 57-68.

Muller J.C., Denys D., Morlet G., Mariotti A. (1987) Influence of catch crops on mineral nitrogen leaching and its subsequent plant use, in: Jenkinson D.S., Smith K.A. (Eds.), Nitrogen Efficiency in Agricultural Soils, Vol. 2, Elsevier, New York.
Newman Y.C., Wright D.W., Mackowiak C., Scholberg J.M.S., Cherr C.M. (2007a) Benefits of Cover Crops for Soil Health, University of Florida, IFAS Extension, SS AGR 272 (http://edis.ifas.ufl.edu/ pdffiles/AG/AG27700.pdf).

Newman Y.C., Wright D.L., Mackowiak C., Scholberg J.M.S., Cherr C.M., Chambliss C.G. (2007b) Cover Crops. University of Florida, IFAS Extension, SS-AGR-66 (http://edis.ifas.ufl.edu/pdffiles/AA/ AA21700.pdf).

Patrick W.H., Haddon C.B., Hendrix J.A. (1957) The effects of longtime use of winter cover crops on certain physical properties of commerce loam, Soil Sci. Soc. Am. J. 21, 366-368.

Reeves D.W. (1997) The role of soil organic matter in maintaining soil quality in continuous cropping systems, Soil Till. Res. 43, 131-167.

Reeves D.W., Tyler D.D., Hargrove W.L. (1995) Winter cover crops, in: Langdale G.W., Moldenhauer W.C. (Eds.), Crop residue management to reduce erosion and improve soil quality: Southeast Conserv. Res. Rep. 39, USDA-ARS, Washington, DC, USA, pp. 27-30.

Sainju U.M., Singh B.P., Whitehead W.F. (2002) Long-term effects of tillage, cover crops, and nitrogen fertilization on organic carbon and nitrogen concentrations in sandy loam soils in Georgia, USA, Soil Till. Res. 63, 167-179.

SAS Institute (2004) The SAS system for Windows, v. 9.1.2. SAS, Inct., Cary, NC, USA.

Sharpley A.N., Smith S.J. (1991) Effects of cover crops on surface water quality, in: Hargrove W.L. (Ed.), Cover crops for clean water, Soil Water Conserv. Soc., Ankeny, IA, USA, pp. 41-49.

Spiertz J.H.J. (2009) Nitrogen, sustainable agriculture and food security. A review, Agron Sustain. Dev., DOI: 10.1051/agro/2008064.

Sullivan P.G., Parrish D.J., Luna J.M. (1991) Cover crop contributions to $\mathrm{N}$ supply and water conservation in corn production, Am. J. Alternative Agric. 6, 106-115.

Sunaga Y., Harada H., Kawachi T., Hatanaka T., Ebato M. (2006) Simple technique for estimating nitrate nitrogen concentration of Italian ryegrass (Lolium multiflorum Lam.) at the heading stage using a chlorophyll meter, Grassland Sci. 52, 133-140.

Vidal M., López A. (2005) Cover crops and organic amendments to prevent nitrate contamination under a wet climate, Agron. Sustain. Dev. 25, 455-463.

Wood C.W., Reeves D.W., Duffield R.R., Edmisten K.L. (1992) Field chlorophyll measurements for evaluation of corn nitrogen status, J. Plant Nutr. 15, 487-500.

Wright D., Marois J., Katsvairo T., Wiatrak P., Rich J. (2004) Value of perennial grasses in conservation cropping systems, Proc. 26th Southern Conserv. Tillage Conf. Sustain. Agric., Raleigh, NC, USA, 8-9 June 2004, pp. 135-142.

Zhao D., Wright L.D., Marois, J.J. (2009) Peanut yield and grade responses to timing of bahiagrass termination and tillage in a sodbased crop rotation, Peanut Sci. 36, 196-203.

Zotarelli L., Avila L., Scholberg J.M.S., Alves B.J.R. (2009) Benefits of vetch and rye cover crops to sweet corn under no-tillage, Agron. J. $101,252-260$.

Zuazo V.H.D., Pleguezuelo C.R.R. (2008) Soil-erosion and runoff prevention by plant covers. A review, Agron. Sustain. Dev. 28, 65-86. 